Chapman University

Chapman University Digital Commons

Pharmacy Faculty Articles and Research

School of Pharmacy

2014

\title{
Amphiphilic Triazolyl Peptides: Synthesis and Evaluation as Nanostructures
}

\author{
Naser Sayeh \\ University of Rhode Island \\ Amir Nasrolahi Shirazi \\ Chapman University, shirazi@chapman.edu \\ Donghoon $\mathrm{Oh}$ \\ University of Rhode Island \\ Jiadong Sun \\ University of Rhode Island \\ David Rowley \\ University of Rhode Island \\ See next page for additional authors
}

Follow this and additional works at: http://digitalcommons.chapman.edu/pharmacy_articles

Part of the Amino Acids, Peptides, and Proteins Commons, and the Nanotechnology Commons

\section{Recommended Citation}

Sayeh, N., Nasrolahi Shirazi, A., Oh, D., Sun, J., Rowley, D., Banerjee, A., Yadav, A., Tiwari, R. K., Parang, K. Amphiphilic triazolyl peptides: Synthesis and evaluation as nanostructures. Current Org. Chem. (2014) 18, 2665-2671.

doi: $10.2174 / 138527281820141028110625$

This Article is brought to you for free and open access by the School of Pharmacy at Chapman University Digital Commons. It has been accepted for inclusion in Pharmacy Faculty Articles and Research by an authorized administrator of Chapman University Digital Commons. For more information, please contact laughtin@chapman.edu. 


\section{Amphiphilic Triazolyl Peptides: Synthesis and Evaluation as Nanostructures}

\section{Comments}

This is a pre-copy-editing, author-produced PDF of an article accepted for publication in Current Organic Chemistry, volume 18, 2014 following peer review. The definitive publisher-authenticated version is available online at DOI: 10.2174/138527281820141028110625.

\section{Copyright}

Bentham Science Publishers

\section{Authors}

Naser Sayeh, Amir Nasrolahi Shirazi, Donghoon Oh, Jiadong Sun, David Rowley, Antara Banerjee, Arpita Yadav, Rakesh Tiwari, and Keykavous Parang 


\title{
Amphiphilic Triazolyl Peptides: Synthesis and Evaluation as Nanostructures
}

\author{
Naser Sayeh, ${ }^{\text {a }}$ Amir Nasrolahi Shirazi, ${ }^{\text {a,b }}$ Donghoon Oh, ${ }^{\text {a }}$ Jiadong Sun, ${ }^{\text {a }}$ David Rowley, \\ Antara Banerjee, ${ }^{\mathrm{c}}$ Arpita Yadav, ${ }^{\mathrm{c}}$ Rakesh Kumar Tiwari, ${ }^{\mathrm{a}, \mathrm{b}, *}$ Keykavous Paranga,b,* \\ ${ }^{a}$ Department of Biomedical and Pharmaceutical Sciences, College of Pharmacy, University of Rhode Island, \\ Kingston, Rhode Island, 02881, United States \\ ${ }^{b}$ Chapman University School of Pharmacy, Irvine, CA, 92618, United States \\ ${ }^{c}$ Department of Chemistry, University Institute of Engineering and Technology, Chhatrapati Shahuji Maharaj \\ University, Kanpur 208024, India
}

\begin{abstract}
A new class of amphiphilic triazolyl peptides was designed and synthesized from peptide-based building blocks containing alkyne and azide functional groups namely linear $(\mathrm{W}(\mathrm{pG}))_{3}$, cyclic $[\mathrm{W}(\mathrm{pG})]_{3}$, and Ac-K $\left(\mathrm{N}_{3}\right) \mathrm{R}-\mathrm{NH}_{2}$, where $\mathrm{W}, \mathrm{R}, \mathrm{K}$, and pG represent tryptophan, arginine, lysine, and propargylglycine residues, respectively. The linear $\left(\mathrm{W}(\mathrm{pG})_{3}\right.$ and cyclic $[\mathrm{W}(\mathrm{pG})]_{3}$ peptides containing alkyne residues were conjugated with $\mathrm{Ac}-\mathrm{K}\left(\mathrm{N}_{3}\right) \mathrm{R}-\mathrm{NH}_{2}$ functionalized with azide group through click chemistry in the presence of $\mathrm{CuSO}_{4} .5 \mathrm{H}_{2} \mathrm{O}, \mathrm{Cu}$ (powder), sodium ascorbate, and $\mathrm{N}, \mathrm{N}$-disopropylethylamine in methanol:water to afford amphiphilic triazolyl linear-linear $\left(\mathrm{WG}(\text { triazole-KR-NH})_{2}\right)_{3}$ and cyclic-linear $\left[\mathrm{WG}(\text { triazole-KR-NH} 2)_{3}\right.$ peptides, respectively. The secondary structures of both peptides were similar to a distorted $\alpha$-helix as shown by CD spectroscopy. TEM imaging showed that linear-linear (WG(triazole-KR-NH$\left.)_{3}\right)_{3}$ and cyclic-linear $\left[\mathrm{WG}\left(\text { triazole- } \mathrm{KR}-\mathrm{NH}_{2}\right)\right]_{3}$ peptides formed nano-sized structures in the size range of 50-100 $\mathrm{nm}$ and 50-80 $\mathrm{nm}$, respectively.
\end{abstract}

Keywords: Amphiphiles, Click chemistry, Cyclic peptides, Nanoparticles, Peptides, Triazole

\section{INTRODUCTION}

Design and synthesis of well-defined materials in nano-sized structures have turned into an important field in biomaterials science and biomedicine [1, 2]. Different intra and intermolecular forces, such as electrostatic interaction, hydrogen bonding, hydrophobic forces, and aromatic stacking contribute to the formation of organized structures [3-5].

Peptides have become a subject of major interest because of their unparalleled potential applications as nanomaterials, surfactants, and drug delivery systems [6-8]. Linear and cyclic peptides containing appropriate amino acids have been shown to undergo self-assembly and generate nanostructures [9]. The generation of self-assembled peptides and nanostructures occurs through various types of interactions between functional groups of amino acid residues, such as electrostatic, hydrophobic, and hydrogen bonding. Appropriate design and functionalization of peptides are critical for generating nanostructures.

Peptides are divided into two major groups namely linear and cyclic. Linear peptides adopt higher flexibility in a solution compared to their cyclic counterparts. Moreover, peptide cyclization has been used as an effective strategy to decrease the conformational freedom of the peptides and to improve the stability against different proteolytic enzymes, such as trypsin, $\alpha$-chymotrypsin, and dipeptidyl-peptidase IV [10]. It has been previously shown that linear peptides containing hydrophilic and hydrophobic amino acids could act as membrane protein stabilizers [11]. However, cyclic peptides containing hydrophilic and hydrophobic amino acids have shown greater potential as stabilizing agents due to their enhanced chemical and enzymatic stability [12]. The self-assembly of peptides has drawn significant attention because of their simple structures and their ability to incorporate multiple inter- and intramolecular forces [13]. Depending on the desired application, various properties including polarity, hydrophobicity, and charge in the structure of peptides can be manipulated by using different numbers of amino acids to find an optimized balance among different forces for self-assembly. Furthermore, the biocompatibility and low toxicity of peptides have made them attractive tools in biomedical investigations [14]. Thus, self-assembled peptide nanostructures have employed as biomaterials [15], drug delivery systems [16], protein stabilizers [17], and antimicrobial agents [18].

We have previously reported design and synthesis of linear and cyclic peptides containing different L-amino acids with hydrophobic (e.g., W, F, L) and charged residues (e.g., K, R, E) by using 9-fluorenylmethyloxycarbonyl (Fmoc)-based peptide chemistry. Among all the designed peptides, [WR $]_{4}$ containing alternative tryptophan and arginine residues generated self-assembled nanostructures at room temperature after a specific incubation time ${ }^{6}$ through hydrophobic force, hydrogen bonding, and/or the $\pi-\pi$ stacking interactions between tryptophan residues. A combination of arginine and tryptophan in the structure of cyclic peptides was also found to be an optimal sequence for drug delivery applications $[7,8]$. Moreover, the cyclic nature of peptides was critical in their biological activities. For example, cyclic peptides with arginine and tryptophan residues exhibited higher potency in kinase inhibition 
compared to their linear counterparts [19].

Additional studies are required to investigate sequence effects on morphologies, and elucidate the fundamental physical interactions that drive their self-assembly in this class of peptides. In continuation of our efforts to explore amphiphilic peptides containing tryptophan and arginine residues as nanostructures, herein we report a novel class of amphiphilic triazolyl peptides containing tryptophan-based cyclic and linear peptides linked through triazole to positively charged linear peptides. Click chemistry was used to attach the cyclic and linear building block peptides containing alkyne with linear peptides functionalized with azide residues to generate cyclic-linear or linear-linear clicked products.

\section{EXPERIMENTAL SECTION}

\section{General}

Reactions were carried out in Bio-Rad polypropylene columns by shaking and mixing in Glass-Col small tube rotator under dry conditions at room temperature. Peptides were synthesized by solid-phase synthesis using $N$-(9-fluorenyl)methoxycarbonyl(Fmoc)-based chemistry and employing Fmoc-L-amino acid building blocks. H-Trp(Boc)-2-chlorotrityl resin and/or Rink amide resin were used for the synthesis of cyclic and linear peptides, respectively. For the coupling of amino acids, Fmoc-Trp(Boc)-OH and Fmoc-L-propargylglycine were used alternatively.

2-(1H-Benzotriazole-1-yl)-1,1,3,3-tetramethyluronium hexafluorophosphate (HBTU)

$N, N$-diisopropylethylamine (DIPEA)

and

$N, N$-dimethylformamide (DMF) were used as coupling and activating reagents, respectively. Rink amide resin, H-Trp(Boc)-2-chlorotrityl resin, coupling reagents, and Fmoc-amino acid building blocks were purchased from Chempep (Miami, FL). Other chemicals and reagents were purchased from Sigma-Aldrich Chemical Co. (Milwaukee, WI). Fmoc deprotection at each step was carried out using piperidine in DMF $(20 \% \mathrm{v} / \mathrm{v})$. The crude peptides were purified by using a reversed-phase Hitachi HPLC (L-2455) on a Gemini C18 column $(250 \mathrm{~mm} \times 21.20 \mathrm{~cm}, 10 \mu \mathrm{m})$ and a gradient system. The peptides were separated by eluting the crude peptides at $10.0 \mathrm{~mL} / \mathrm{min}$ using a gradient of $0-100 \%$ acetonitrile $(0.1 \%$ trifluoroacetic acid (TFA)) and water $(0.1 \%$ TFA) over $60 \mathrm{~min}$, and then were lyophilized. The purity of final products $(\geq 95 \%)$ was confirmed by analytical HPLC. The chemical structures of the building block peptides and final products were confirmed by high-resolution MALDI AXIMA performance TOF/TOF mass spectrometer (Shimadzu Biotech) or a high-resolution Biosystems QStar Elite time-of-flight electrospray mass spectrometer.

Synthesis of Linear Peptide (W(pG)) 3. The linear peptide was assembled on Rink amide resin $(0.59 \mathrm{~g}, 0.4 \mathrm{mmol}, 0.68$ $\mathrm{mmol} / \mathrm{g}$ ) by solid-phase Fmoc/tBu peptide synthesis strategy using Fmoc-protected amino acids [Fmoc-Trp(Boc)-OH and Fmoc-L-Propargylglycine] (Scheme 1). The linear peptide sequence was assembled on the resin after removing the Fmoc group at the $N$ terminal in the presence of $20 \%$ piperidine in DMF $(\mathrm{v} / \mathrm{v})$ to obtain the sequence $\mathrm{NH}_{2}-(\mathrm{pG}) \mathrm{W}(\mathrm{Boc})(\mathrm{pG}) \mathrm{W}(\mathrm{Boc})(\mathrm{pG}) \mathrm{W}($ Boc $)$-Rink amide resin. The resin was washed with DMF (3 times, $15 \mathrm{~mL}$ ) and DCM $(3 \times 15 \mathrm{~mL})$ to remove any traces of piperdine. The peptidyl resin was dried in vacuum for $24 \mathrm{~h}$. A freshly prepared reagent $\mathrm{R}$ cleavage cocktail trifluoroacetic acid (TFA)/thioanisole/ethandithol (EDT)/anisole (90:5:3:2, $\mathrm{v} / \mathrm{v} / \mathrm{v} / \mathrm{v}, 15 \mathrm{~mL}$ ) was added to the resin, and the resin was agitated at room tempertuare for $2 \mathrm{~h}$. The resin was collected by filtration and consequently washed with $2 \mathrm{~mL}$ of reagent $\mathrm{R}$. The crude peptide was precipitated by adding peptide filterates to cold diethyl ether $\left(200 \mathrm{~mL}, \mathrm{Et}_{2} \mathrm{O}\right)$ and centrifuged at $4000 \mathrm{rpm}$ for $5 \mathrm{~min}$ followed by decantation to obtain the solid precipitate. The solid material was further washed with cold ether $(2 \times 100 \mathrm{~mL})$. The peptide was lyophilized and purified by reversed-phase Hitachi HPLC using a gradient system as described above to yield solid white coloured linear peptide $(\mathrm{W}(\mathrm{pG}))_{3}$. MALDI-TOF $(\mathrm{m} / \mathrm{z})$ [C $\left.\mathrm{C}_{48} \mathrm{H}_{47} \mathrm{~N}_{9} \mathrm{O}_{7}\right]$ : calcd, 860.3758; found, $884.3489[\mathrm{M}+\mathrm{Na}+$ $\mathrm{H}]^{+}$.

Synthesis of Cyclic Peptide [W(pG)]3. The linear protected peptide sequence was assembled using H-Trp(Boc)-2-chlorotrityl resin $(0.51 \mathrm{~g}, 0.4 \mathrm{mmol}, 0.78$ $\mathrm{mmol} / \mathrm{g})$. The resin was swelled using DMF $(3 \times 30 \mathrm{~mL}, 10$ min) followed by coupling with appropriate amino acids (Fmoc-Trp(Boc)-OH and Fmoc-L-propargylglycine) and deprotection cycle with piperidine in DMF (20\% v/v). The final $N$-terminal Fmoc group was removed to assemble the sequence on the peptidyl resin, $\mathrm{NH}_{2}$-(pG)W(Boc)(pG)W(Boc)(pG)W(Boc)-2-chlorotrityl resin (Scheme 2). The resin was washed with DMF $(3 \times 15$ $\mathrm{mL})$ and $\mathrm{DCM}(3 \times 15 \mathrm{~mL})$ to remove any traces of piperdine. Side chain-protected peptides were cleaved from the resins by agitating the peptidyl resin with cleavage cocktail, acetic acid/ 2,2,2-trifluoroethanol (TFE)/dichloromethane $(1: 2: 7, \mathrm{v} / \mathrm{v} / \mathrm{v}, 50 \mathrm{~mL})$ for $1 \mathrm{~h}$ at room temperature followed by filtration and washing the resin with TFE:DCM $(2: 8 \mathrm{v} / \mathrm{v}, 20 \mathrm{~mL})$. The collected filterate was evaporated to reduce volume residue. Hexane $(2 \times 25 \mathrm{~mL})$ and DCM $(1 \times 25 \mathrm{~mL})$ were added to the residue to remove the acetic acid from the residue. The solvents were evaporated to yield a floopy white solid compound that was dried overnight. The cyclization of the protected crude solid peptide was carried out in the presence of a mixture of coupling reagents, 1-hydroxy-7-azabenzotriazole (HOAt) (162 $\mathrm{mg}, \quad 0.4 \mathrm{mmol}$ ) and $N, N^{\prime}$-diisopropylcarbodiimide (DIC) $(310 \mu \mathrm{L}, 0.4 \mathrm{mmol})$ in anhydrous DMF:DCM (60/200 $\mathrm{mL})$ for $24 \mathrm{~h}$. The solvent was evaporated from a sample solution $(5 \mathrm{~mL})$ under reduced pressure, and the residue was cleaved with reagent $\mathrm{R}$ that confirmed the cyclization by mass spectrometry. Thus, all the solvents were removed under reduced pressure that generated a high viscous liquid. The final peptide cleavage to remove the side chain protection was carried out by shaking the residue with cleavage cocktail, reagent $\mathrm{R}$, TFA/thioanisole/anisole/EDT 
(90:5:2:3 v/v/v/v, $15 \mathrm{~mL}$ ) for $2 \mathrm{~h}$ at room tempertuare. The crude peptide was precipitated by the addition of cold diethyl ether $\left(200 \mathrm{~mL}, \mathrm{Et}_{2} \mathrm{O}\right)$ and centrifuged at $4000 \mathrm{rpm}$ for $5 \mathrm{~min}$ followed by decantation to obtain the solid precipitate. The solid material was further washed with cold ether $(2 \times 100 \mathrm{~mL})$. The crude peptide was lyophilized and purified by reversed-phase Hitachi HPLC (L-2455) as described above to yield cyclic peptide $[\mathrm{W}(\mathrm{pG})]_{3}$. MALDI-TOF (m/z) [ $\left.\mathrm{C}_{48} \mathrm{H}_{45} \mathrm{~N}_{9} \mathrm{O}_{6}\right]$ : calcd, 843.3493; found 866.2380 [M+Na $]^{+}$.

Synthesis of Azide functionalised Positively Charged Peptide (Ac-K(N) $\left.\left(\mathbf{N}_{3}\right) \mathbf{R}-\mathbf{N H}_{2}\right)$. The peptide was assembled on Rink amide resin (294 mg, $0.2 \mathrm{mmol}, 0.68 \mathrm{mmol} / \mathrm{g}$ ) by solid-phase peptide synthesis using Fmoc-protected amino acids, Fmoc-Arg(Pbf)-OH and Fmoc-Lys $\left(\mathrm{N}_{3}\right)-\mathrm{OH}$. The Rink amide resin was swelled with DCM $(50 \mathrm{~mL}, 10 \mathrm{~min})$ and then DMF $(50 \mathrm{~mL}, 2 \times 10 \mathrm{~min})$. The Fmoc group on the resin was deprotected by piperidine in DMF $(20 \%$, v/v, 25 $\mathrm{mL}, 2 \times 10 \mathrm{~min})$ follwed by washing with $\mathrm{DMF}(3 \times 30 \mathrm{~mL})$. Fmoc-Arg (pbf)-OH (389 mg, $0.2 \mathrm{mmol} / \mathrm{g}$ ) was then coupled to the peptidyl resin in the presence of coupling reagents HBTU (228 mg, $0.2 \mathrm{mmol} / \mathrm{g})$ and DIPEA $(210 \mu \mathrm{L})$ in $N, N$-dimethylformamide (DMF, $10 \mathrm{~mL}$ ). The mixture was agitated at room tempertuare for $1 \mathrm{~h}$. The resin was then washed with DMF $(3 \times 10 \mathrm{~mL})$ for $5 \mathrm{~min}$. The Fmoc group was deprotected using using piperidine in DMF $(20 \% \mathrm{v} / \mathrm{v}$, $25 \mathrm{~mL}, 2 \times 10 \mathrm{~min})$ followed by washing with DMF $(3 \times 20$ $\mathrm{mL})$. The Fmoc-Lys $\left(\mathrm{N}_{3}\right)-\mathrm{OH}(173 \mathrm{mg}, 0.2 \mathrm{mmol})$ was coupled by using HBTU (228 mg, $0.2 \mathrm{mmol}$ ), DIPEA (210 $\mu \mathrm{L})$ in DMF for $1 \mathrm{~h}$. The resin was washed with DMF $(3 \times$ $20 \mathrm{~mL}$ ), and Fmoc group was deprotected by using piperdine in $\operatorname{DMF}(20 \% \mathrm{v} / \mathrm{v}, 25 \mathrm{~mL}, 2 \times 10 \mathrm{~min})$. The resin was washed with DMF followed by capping the amino group by acetic anhdyride $\left(\mathrm{AC}_{2} \mathrm{O}, 95 \mu \mathrm{L}, 1 \mathrm{mmol}\right)$ and DIPEA $(174 \mu \mathrm{L}, 1 \mathrm{mmol})$ in anhdyrous DMF $(3 \mathrm{~mL})$ for 30 min. The resin was washed with DMF $(3 \times 30 \mathrm{~mL})$, DCM $(3$ $\times 30 \mathrm{~mL}$ ), and was dried in vaccum overnight before the final cleavage. A freshly prepared cleavage cocktail, TFA/triisopropylsilane/water (95:2.5:2.5 v/v/v, $10 \mathrm{~mL})$ was added to the resin and shaken at room temperature for $1.5 \mathrm{~h}$. The resin was filtered and evaporated to reduce the volume under dry nitrogen. The crude peptide was precipitated by adding cold diethyl ether $\left(200 \mathrm{~mL}, \mathrm{Et}_{2} \mathrm{O}\right)$ and centrifuged at $4000 \mathrm{rpm}$ for $5 \mathrm{~min}$ followed by decantation to obtain the solid precipitate. The peptide was purified by reversed-phase Hitachi HPLC using a gradient system, and the HPLC fractions were collected, evaporated and lyophilized to obtain dry product. ESI-TOF $(\mathrm{m} / \mathrm{z})\left[\mathrm{C}_{14} \mathrm{H}_{27} \mathrm{~N}_{9} \mathrm{O}_{3}\right]$ : calcd, 369.2237; found, $370.2144[\mathrm{M}+\mathrm{H}]^{+}$.

Synthesis of Amphiphilic Triazolyl Peptides by Click Chemistry of Peptides (Linear or Cyclic Peptides) with Azide-Functionalized Positively Charged Linear Peptide. The click reaction was carried out in $20 \mathrm{~mL}$ glass vial with small magnetic stir bar by adding the alkyne peptide (linear peptide $(7.46 \mathrm{mg}, 8.68 \mu \mathrm{mol})$ or cyclic peptide $(7.25 \mathrm{mg}$, $8.68 \mu \mathrm{mol})$ ), $\mathrm{CuSO}_{4} .5 \mathrm{H}_{2} \mathrm{O}(6.5 \mathrm{mg}, 0.026$ mmole $), \mathrm{Cu}$ powder (16.5 mg, $0.26 \mathrm{mmol})$, sodium ascorbate $(51.5 \mathrm{mg}$, $0.26 \mathrm{mmol})$, and azide-functionalized peptide, Ac-K $\left(\mathrm{N}_{3}\right) \mathrm{R}_{-} \mathrm{NH}_{2}(10 \mathrm{mg}, 0.026 \mathrm{mmol})$ in methanol:water $(2: 1,5 \mathrm{~mL})$ followed by addition of DIPEA $(9 \mu \mathrm{L}, 0.052$ $\mathrm{mmol})$. The mixture was stirred at room temperature for 24-48 h. The completion of the reaction was confirmed by MALDI mass spectroscopy. The reaction mixture was filtered, and the solvent was evaporated under reduced pressure to afford the crude product. The crude product was further purified by HPLC using a gradient system, and the HPLC fractions were collected, evaporated and lyophilized to obtain solid compounds. Linear-linear $\left(\mathrm{WG}(\text { triazole-KR-NH })_{2}\right)_{3}$, MALDI-TOF $(\mathrm{m} / \mathrm{z})$ $\left[\mathrm{C}_{90} \mathrm{H}_{128} \mathrm{~N}_{36} \mathrm{O}_{16}\right]$ : calcd, 1969.0309; found 1970.2032 [M + $\mathrm{H}]^{+}$; Cyclic-linear [WG(triazole-KR-NH 2$\left.)\right]_{3}$ MALDI-TOF $(\mathrm{m} / \mathrm{z})\left[\mathrm{C}_{90} \mathrm{H}_{126} \mathrm{~N}_{36} \mathrm{O}_{15}\right]$ : calcd, 1951.0203; found 1951.6645 $[\mathrm{M}]^{+}$.

Circular Dichroism. CD spectra were recorded on a JASCO J-810 spectropolarimeter using $1 \mathrm{~mm}$ path length cuvettes. The scan speed was $100 \mathrm{~nm} / \mathrm{min}$, and spectra were averaged over 8 scans. All experiments on the samples including cyclic-linear $[\mathrm{WG}(\text { triazole-KR-NH})]_{3}$ and linear-linear (WG(triazole-KR-NH $\left.)_{2}\right)_{3}\left(1 \mathrm{mM}, \mathrm{H}_{2} \mathrm{O}\right)$ were tested at room temperature. The $\mathrm{CD}$ for background reference (water) was measured and subtracted from the sample.

Transmission Electron Microscopy (TEM). TEM analyses were conducted in JEOL Transmission Electron Microscope (Tokyo, Japan) at an accelerating voltage $80 \mathrm{keV}$. The stock solution $(1 \mathrm{mM})$ in deionized water incubated for 3 days was used for the sample preparation. TEM samples of cyclic-linear $\left[\mathrm{WG}\left(\text { triazole-KR-NH} \mathrm{NH}_{2}\right]_{3}\right.$ and linear-linear (WG(triazole-KR-NH$\left.)_{2}\right)_{3}$ were prepared by depositing a droplet of $5 \mu \mathrm{L}$ of $1 \mathrm{mM}$ solution in $\mathrm{H}_{2} \mathrm{O}$ on a carbon-coated $\mathrm{Cu}$ support grid of mesh size 300, which was allowed to rest for $2 \mathrm{~min}$. After drop casting of peptide solution, the grids were then stained with uranyl acetate $(20 \mathrm{~mL})$ for $2 \mathrm{~min}$. Excess stain was removed, and the grids were allowed to dry overnight.

\section{Molecular Modeling.}

Cyclic-linear $[\mathrm{WG}(\text { triazole-KR-NH})]_{3}$ monomer was built using GaussView software and completely optimized without any constraints utilizing Gaussian'03 software. Charge density was plotted and colored according to electrostatic potential.

\section{RESULTS AND DISCUSSION}

Click chemistry has been previously used to design diverse structures of peptide scaffolds. For instance, different derivatives of a triazole-containing kinase inhibitor cyclo-[Pro-Val-Pro-Tyr] peptide were synthesized through click chemistry [20]. Furthermore, triazoles were found to be appropriate substituent for the amide bond in peptides with a $\alpha$-helical structure [21]. Horne et al. designed a class 
of cyclic peptides containing 1,4- or 1,5-disubstituted 1,2,3-triazoles [22] that were found to be able to serve as surrogates for trans or cis amide bonds, respectively. Synthesis of amphiphilic peptides containing hydrophobic and positively charged residues by click chemistry remains unexplored. To the best of our knowledge, this is the first report of amphiphilic cyclic-linear and linear-linear peptides linked through a triazole spacer.

The synthesis of linear-linear (WG(triazole)-KR $)_{3}$ and cyclic-linear $[\mathrm{WG}(\text { triazole })-\mathrm{KR}]_{3}$ peptides containing triazole rings were performed in two major steps by synthesizing the building blocks containing alkyne and azide residues. First, linear $(\mathrm{W}(\mathrm{pG}))_{3}$ and cyclic $[\mathrm{W}(\mathrm{pG})]_{3}$ building block peptides (where $(\mathrm{pG})=$ propargylglycine) containing alkyne residues were synthesized by Fmoc-based chemistry. Second, a building block containing azide residue, Ac-K( $\left.\mathrm{N}_{3}\right) \mathrm{R}-\mathrm{NH}_{2}$, was synthesized. Finally, the building blocks were conjugated with each other through click chemistry.

The linear peptide $(\mathrm{W}(\mathrm{pG}))_{3}$ was assembled on Rink amide resin $(0.4 \mathrm{mmol}, 0.68 \mathrm{mmol} / \mathrm{g})$ by solid-phase $\mathrm{Fmoc} / \mathrm{tBu}$ peptide synthesis strategy using Fmoc-Trp(Boc)-OH and Fmoc-L-propargylglycine (Scheme 1). The peptide sequence was assembled on the resin followed by removing of the $N$-terminal Fmoc group to obtain the sequence $\mathrm{NH}_{2}-(\mathrm{pG}) \mathrm{W}(\mathrm{Boc})(\mathrm{pG}) \mathrm{W}$ (Boc)(pG)W(Boc)-Rink amide resin. The linear peptide was obtained after cleavage of peptidyl resin using reagent $\mathrm{R}$ cleavage cocktail (trifluoroacetic acid (TFA)/thioanisole/ethanedithiol (EDT)/anisole (90:5:3:2, v/v/v/v)) by shaking the mixture at room temperature for $2 \mathrm{~h}$, followed by precipitation with cold ether and centrifugation to afford solid crude linear $(\mathrm{W}(\mathrm{pG}))_{3}$ peptide, which was further purified by using HPLC.

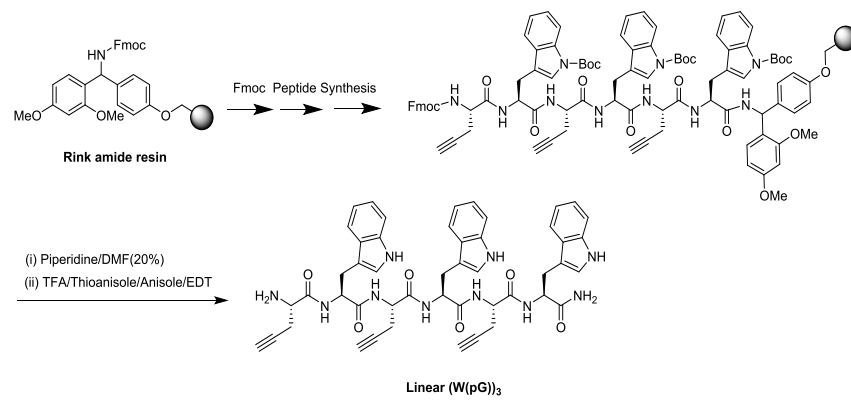

Scheme 1. Synthesis of linear $(\mathrm{W}(\mathrm{pG}))_{3}$ as the building block.

In contrast with the synthetic procedure for the linear peptide, cyclic peptide $[\mathrm{W}(\mathrm{pG})]_{3}$ was synthesized by using H-Trp(Boc)-2-chlorotrityl resin (0.4 mmol, $0.78 \mathrm{mmol} / \mathrm{g}$, (Scheme 2). The resin was swelled using DMF followed by coupling and deprotection cycles using appropriate amino acids and piperidine in DMF $(20 \% \mathrm{v} / \mathrm{v})$. The final
$N$-terminal Fmoc group was removed to assemble the sequence on the peptidyl resin, $\mathrm{NH}_{2}-(\mathrm{pG}) \mathrm{W}(\mathrm{Boc})(\mathrm{pG}) \mathrm{W}(\mathrm{Boc})(\mathrm{pG}) \mathrm{W}($ Boc $)$-2-chlorotrityl resin. The side chain protected peptide was cleaved from the resin by agitating the resin with cleavage cocktail, acetic acid/2,2,2-trifluoroethanol (TFE)/dichloromethane (1:2:7, $\mathrm{v} / \mathrm{v} / \mathrm{v}$ ) for $1 \mathrm{~h}$ at room temperature followed by filtration and evaporation of cocktail liquid to afford the crude side chain protected peptide. The peptide was dried overnight followed by $N$ - to $C$-terminal cyclization by using coupling reagents, 1-hydroxy-7-azabenzotriazole (HOAt) and $N, N^{\prime}$-diisopropylcarbodiimide (DIC) in DMF/DCM under diluted conditions for overnight. The progress of the reaction was monitored by using MALDI-TOF. The solvent was evaporated and Boc protecting groups were removed in the presence of reagent $\mathrm{R}$ cleavage cocktail for $2 \mathrm{~h}$ followed by precipitation and HPLC purification to afford the cyclic peptide.

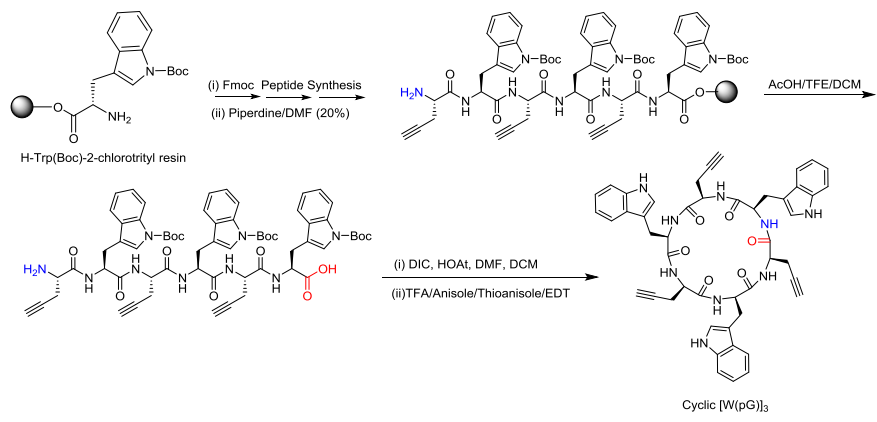

Scheme 2. Synthesis of cyclic $[\mathrm{W}(\mathrm{pG})]_{3}$ as the building block.

The synthesis of azide-functionalized positively charged peptide building block $\left(\mathrm{Ac}-\mathrm{K}\left(\mathrm{N}_{3}\right) \mathrm{R}-\mathrm{NH}_{2}\right)$ was performed on Rink amide resin $(0.2 \mathrm{mmol}, 0.68 \mathrm{mmol} / \mathrm{g})$ using building blocks of Fmoc-protected amino acids including Fmoc-Arg(pbf)-OH and Fmoc-Lys $\left(\mathrm{N}_{3}\right)-\mathrm{OH}$. The resin was swelled and deprotected to couple arginine followed by deprotection and coupling with Fmoc-Lys $\left(\mathrm{N}_{3}\right)-\mathrm{OH}$. The Fmoc group was deprotected, and amino group was further capped using acetic anhydride in DMF. The peptide was cleaved from the resin using a cleavage cocktail containing TFA/TIS/ $\mathrm{H}_{2} \mathrm{O}(95: 2.5: 2.5, \mathrm{v} / \mathrm{v} / \mathrm{v})$ and purified by HPLC to afford $\mathrm{Ac}-\mathrm{K}\left(\mathrm{N}_{3}\right) \mathrm{R}-\mathrm{NH}_{2}$ (Scheme 3). 


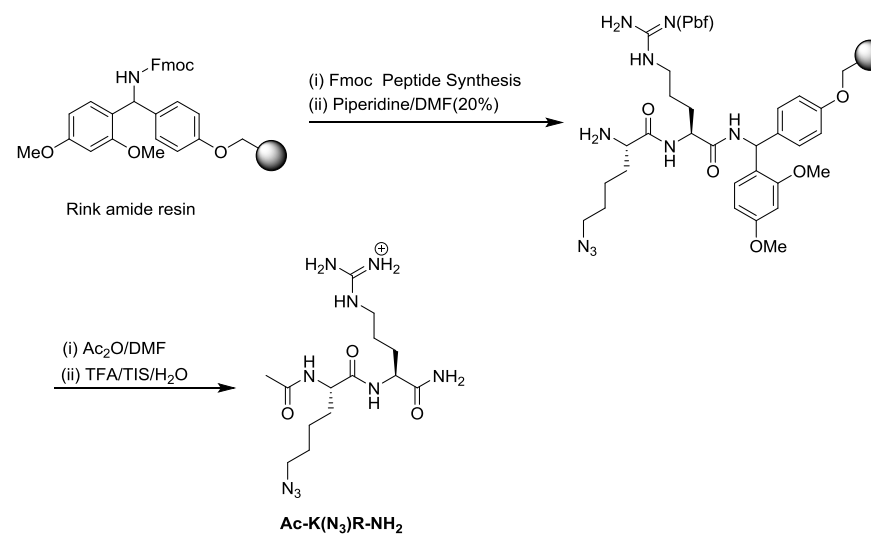

Scheme 3. Synthesis of positively charged peptide containing azide as the building block.

Finally, the linear-linear and cyclic-linear amphiphilic triazolyl peptides were synthesized by click reaction between the linear or cyclic peptides containing alkyne, $(\mathrm{W}(\mathrm{pG}))_{3}$ and $[\mathrm{W}(\mathrm{pG})]_{3}$, and azide-functionalized linear peptide $A c-\mathrm{K}\left(\mathrm{N}_{3}\right) \mathrm{R}-\mathrm{NH}_{2}$ in solution phase using $\mathrm{CuSO}_{4} \cdot 5 \mathrm{H}_{2} \mathrm{O}, \quad \mathrm{Cu}$ powder, sodium ascorbate, and $\mathrm{N}, \mathrm{N}$-diisopropylethylamine (DIPEA) in methanol:water for 24-48 $\mathrm{h}$ (Scheme 4). The azide peptide Ac- $\mathrm{K}\left(\mathrm{N}_{3}\right) \mathrm{R}-\mathrm{NH}_{2}$ was used in excess (more than 3 equiv) to conjugate with the three alkyne functional groups in the linear or cyclic peptides at room temperature and afford the linear-linear $\left(\mathrm{WG}\left(\text { triazole- } \mathrm{KR}^{-} \mathrm{NH}_{2}\right)\right)_{3}$ and cyclic-linear

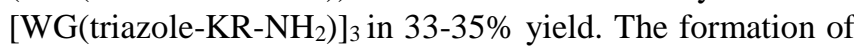
the conjugated 1,4 product was confirmed by MALDI-TOF mass spectroscopy.

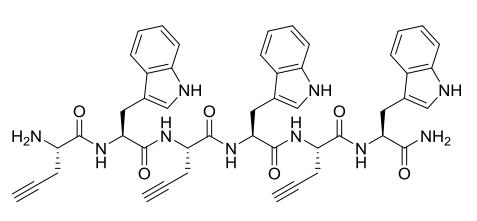

Linear $(W(P G))_{3}$

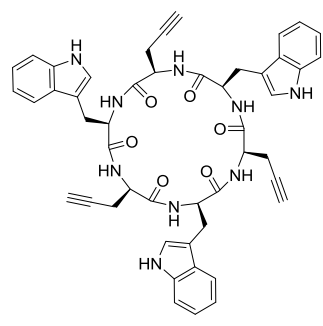

Cyclic $[W(p G)]_{3}$
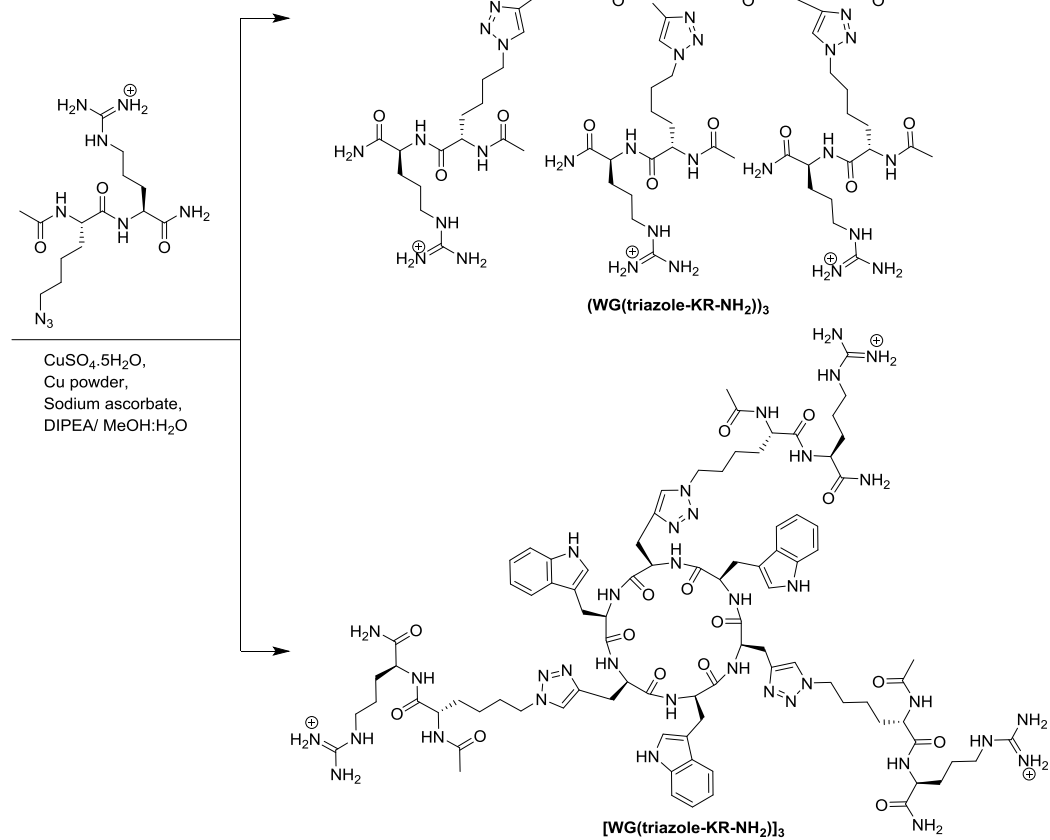

Scheme 4. Synthesis of linear-linear $\left(\mathrm{WG}\left(\text { triazole- } \mathrm{KR}-\mathrm{NH}_{2}\right)\right)_{3}$ and cyclic-linear $\left[\mathrm{WG}\left(\text { triazole- } \mathrm{KR}-\mathrm{NH}_{2}\right)\right]_{3}$

The structure of optimized conformation of cyclic-linear $\left[\mathrm{WG}\left(\text { triazole- } \mathrm{KR}-\mathrm{NH}_{2}\right)\right]_{3}$ monomer was evaluated for charge distribution. The modeling exhibited positively charged arginine extending out of the cyclic peptide (Figure 1). 


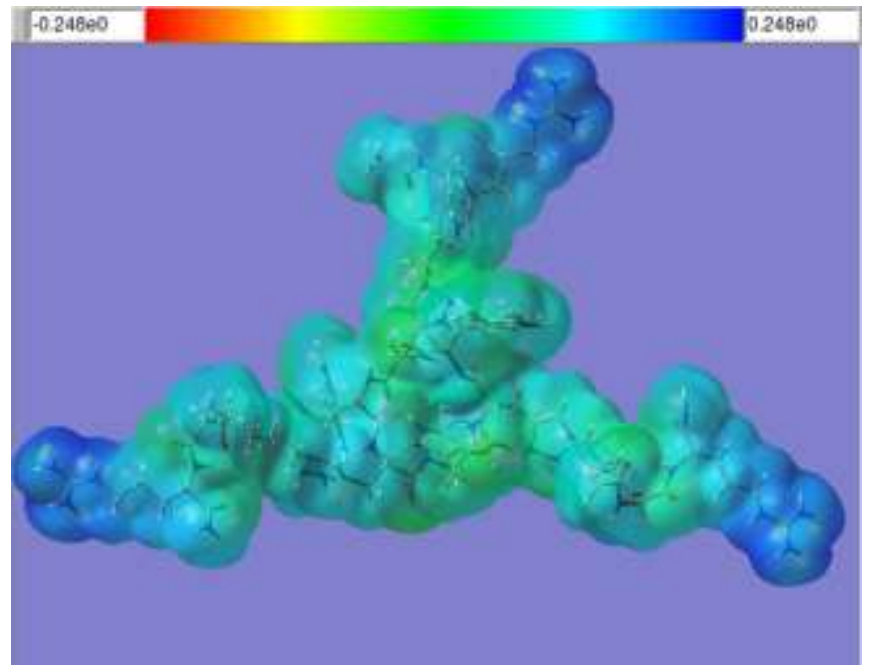

Figure 1. Molecular electrostatic potential surface of $[\mathrm{WG}(\text { triazole-KR-NH})]_{3}$.

The secondary structure of peptides is one of the responsible elements in the self-assembly pattern. Circular dichroism (CD) was employed to obtain insights about the secondary structure of both peptides. The secondary structures of the majority of peptides are divided into three major classic forms namely $\beta$-sheet, $\alpha$-helix, and random coil. The $\beta$-sheet structures get stabilized through available hydrogen bonding between oligopeptide strands. However, intra-chain hydrogen bonds help the $\alpha$-helix to form a stable coiled structure. The CD results showed that both peptides have a relatively similar structure. CD spectra of the cyclic-linear peptide $(1 \mathrm{mM})$ solution in water at room temperature showed two minima peaks at $226 \mathrm{~nm}$ and $199 \mathrm{~nm}$. The linear peptide exhibited a similar CD pattern to the cyclic one with two minima peaks at $226 \mathrm{~nm}$ and $202 \mathrm{~nm}$ (Figure 2). However, a blue shift was found for the cyclic peptide compared to the linear one from 202 to $199 \mathrm{~nm}$, suggesting that the secondary structure of the cyclic peptide is slightly different from the linear one. A distinct $\alpha$-helix structure shows two minima peaks at 222 and $208 \mathrm{~nm}$. Thus, the structures of these peptides did not follow a typical $\alpha$-helical structure.

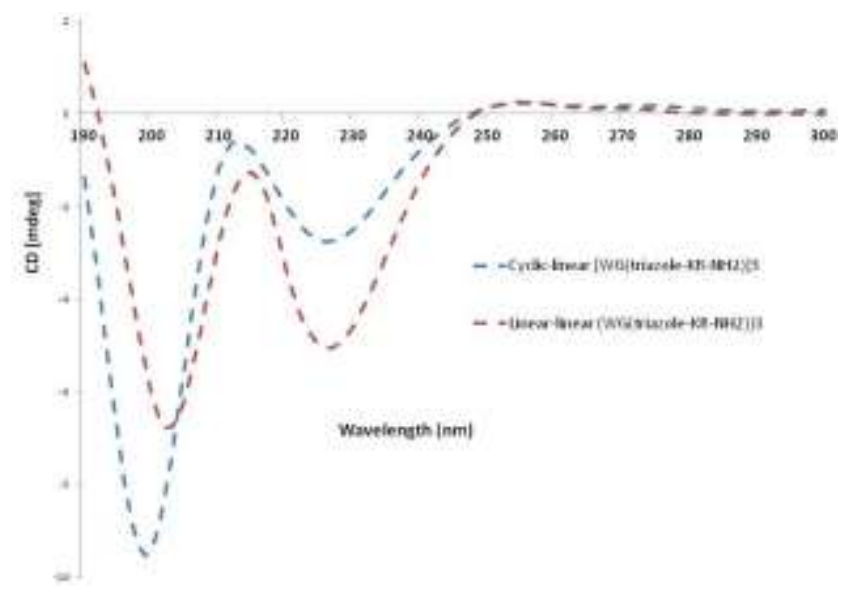

Figure 2. $\mathrm{CD}$ spectra of linear-linear $\left(\mathrm{WG}(\text { triazole-KR-NH})_{2}\right)_{3}$ and cyclic-linear $[\mathrm{WG}(\text { triazole-KR-NH})]_{3}$.

Furthermore, the size and morphologies of peptide nanoparticles were monitored by using transmission electron microscopy (TEM). As it is shown in Figure 3, the cyclic-linear $\left[\mathrm{WG}\left(\text { triazole-KR-NH} \mathrm{N}_{2}\right]_{3}\right.$ formed spherical nanostructures in the size range of 50-80 $\mathrm{nm}$. However, the linear-linear (WG(triazole-KR-NH 2$))_{3}$ exhibited an entirely different morphologies and size compared to that of the cyclic-linear one. The linear peptide showed nanosized network with the small particles as small as 5-10 nm. Small sized particles showed aggregation by forming larger particles in the size range 50-100 nm (Figure 4). Although linear-linear and cyclic-linear peptides share the equal number of similar amino acids, they form different types of particles presumably because of the difference in the orientation of positively charged guanidine groups in arginine and hydrophobic tryptophan residues.
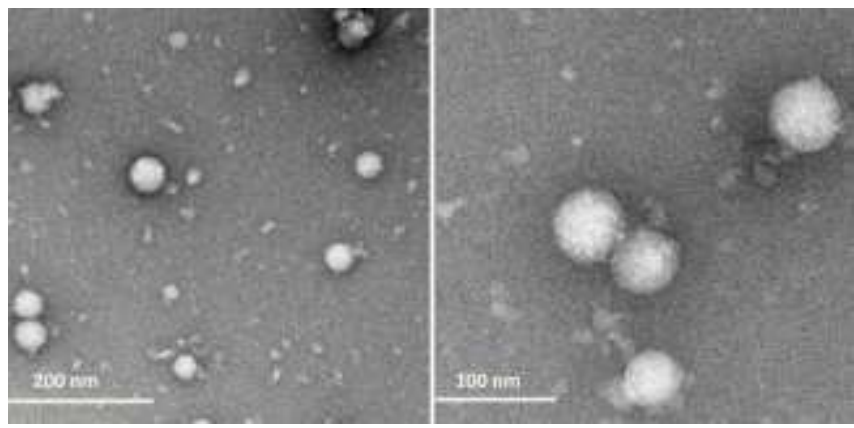

Figure 3. TEM images of cyclic-linear $[\mathrm{WG}(\text { triazole-KR-NH})]_{3}$.

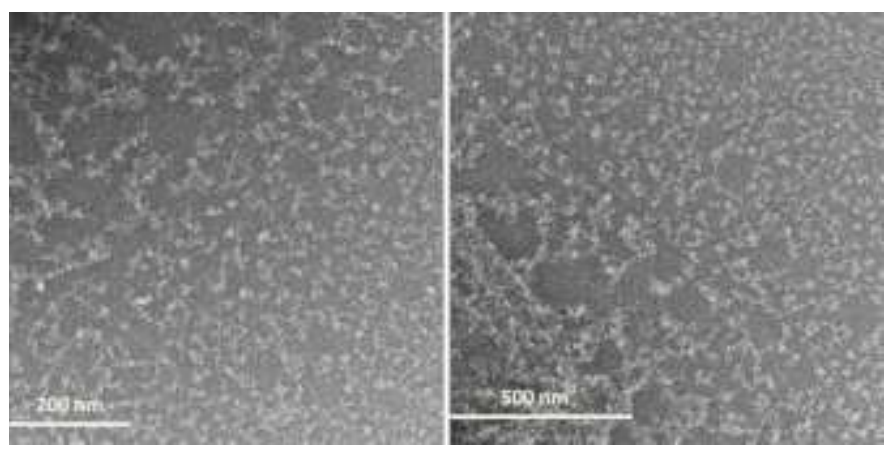

Figure 4. TEM images of linear-linear

$(\mathrm{WG}(\text { triazole-KR-NH}))_{3}$.

\section{CONCLUSION}

In conclusion, a new class of amphiphilic triazolyl peptides containing arginine and tryptophan, linear-linear $\left(\mathrm{WG}(\text { triazole-KR-NH})_{2}\right)_{3}$ and cyclic-linear [WG(triazole-KR-NH $\left.\mathrm{N}_{2}\right]_{3}$, was synthesized by using click chemistry. CD spectroscopy exhibited that the secondary structures of both peptides have a similar pattern. Cyclic-linear $\left[\mathrm{WG}\left(\text { triazole-KR-NH} \mathrm{N}_{2}\right)\right]_{3}$ and linear-linear (WG(triazole-KR-NH$\left.)_{2}\right)_{3}$ showed nano-sized structures in 
a range size of $50-100 \mathrm{~nm}$.

\section{ACKNOWLEDGMENTS}

We thank National Center for Research Resources, NIH, and Grant Number 1 P20 RR16457 for sponsoring the core facility.

\section{References}

[1] Zhang, S. Fabrication of novel biomaterials through molecular self-assembly. Nat. Biotechnol., 2003, 21, 1171-1178.

[2] Krishna, R.; Mayer, D. Multidrug resistance (MDR) in cancer. Mechanisms, reversal using modulators of MDR and the role of MDR modulators in influencing the pharmacokinetics of anticancer drugs. Eur. J. Pharm. Sci., 2000, 11, 265-283.

[3] Whitesides, G.M.; Mathias, J.P.; Set, C.T. Molecular self-assembly and nanochemistry: A chemical strategy for the synthesis of nanostructures. Science, 1991, 254, 1312-1319.

[4] Bryson, J.W.; Betz, S.F.; Lu, H.S.; Suich, D.J.; Zhou, H.X.; O'Neil, K.T.; DeGrado, W. F. Protein design: A hierarchic approach. Science, 1995, 270, 935-941.

[5] Dill, K.A. Dominant forces in protein folding. Biochemistry, 1990, 29, 7133-7155.

[6] Brooks, C.L. Protein and peptide folding explored with molecular simulations. Acc. Chem. Res., 2002, 35, 447-454.

[7] Mandal, D.; Tiwari, R.; Shirazi, A.N.; Oh, D.; Ye, G.; Banerjee, A.; Yadav, A.; Parang, K. Self-assembled surfactant cyclic peptide nanostructures as stabilizing agents. Soft Mater., 2013, 9, 9465-9475.

[8] Mandal, D.; Nasrolahi Shirazi, A.; Parang, K. Cell-penetrating homochiral cyclic peptides as nuclear-targeting molecular transporters. Angew. Chem., Int. Ed., 2011, 50, 9633-9637.

[9] Shirazi, A.N.; Tiwari, R.K.; Chhikara, B.S.; Mandal, D.; Parang, K. Design and biological evaluation of cell-penetrating peptide-doxorubicin conjugates as prodrugs. Mol. Pharm., 2013, 10, 488-499.

[10] Shirazi, A.N.; Mandal, D.; Tiwari, R.K.; Guo, L.; Lu, W.; Parang, K. Cyclic peptide-capped gold nanoparticles as drug delivery systems. Mol. Pharm., 2013, $10,500-511$

[11] Mandal, D.; Shirazi, A.N.; Parang, K. Self-assembly of peptides to nanostructures. Org. Biomol. Chem., 2014, 12, 3544-61.

[12] Vlieghe, P.; Lisowski, V.; Martinez, J.; Khrestchatisky, M. Synthetic therapeutic peptides: science and market Drug. Discov. Today., 2010, 15, 40-56.

[13] Yeh, J.; Du, S.; Tordajada, A.; Paulo, J.; Zhang, S. Peptergents: Peptide detergents that improve stability and functionality of a membrane protein, glycerol-3-phosphate dehydrogenase. Biochemistry, 2005, 44, 16912-16919.

[14] Katsara, M.; Selios, T.T.; Deraos, S.; Deraos, G.; Matsoukas, M.T.; Lazoura, E.; Matsoukas, J.; Apostolopoulos, V. Round and round we go: Cyclic peptides in disease. Curr. Med. Chem., 2006, 13, 2221-2232.

[15] Lehn, J.M. Toward complex matter: Supramolecular chemistry and self-organization. Proc. Natl. Acad. Sci. USA, 2002, 99, 4763-4768.

[16] Bellomo, E.G.; Wyrsta, M.D.; Pakstis, L.; Pochan, D.J.; Deming, T.J. Stimuli-responsive polypeptide vesicles by conformation-specific assembly. Nat. Mater, 2004, 3, 244-248.

[17] Shirazi, A.N.; Oh, D.; Tiwari, R.K.; Sullivan, B, Gupta, A.; Bothun, G.D.; Parang, K. Peptide amphiphile containing arginine and fatty acyl chains as molecular transporters. Mol. Pharm., 2013, 10, 4717-4727.

[18] Kogan, M.J.; Olmedo, I.; Hosta, L.; Guerrero, A.R.; Cruz, L.J.; Albericio, F. Peptides and metallic nanoparticles for biomedical applications. 
Nanomedicine, 2007, 2, 287-306.

[19] Kyle, S.; Aggeli, A.; Ingham, E.; McPherson, M.J. Recombinant self-assembling peptides as biomaterials for tissue engineering. Biomaterials, 2010, 31, 9395-9405.

[20] Shirazi, A.N.; Tiwari, R.K.; Oh, D.; Banerjee, A.; Yadav, A.; Parang, K. Efficient delivery of cell impermeable phosphopeptides by a cyclic peptide amphiphile containing tryptophan and arginine. Mol. Pharm., 2013, 10, 2008-2020.

[21] Shirazi, A.N.; Tiwari, R.K.; Chhikara, B.S.; Mandal, D.; Parang, K. Design and biological evaluation of cell-penetrating peptide-doxorubicin conjugates as prodrugs. Mol. Pharm., 2013, 10, 488-499.

[22] Zelzer, M.; Ulijn, R.V. Next-generation peptide nanomaterials: molecular networks, interfaces and supramolecular functionality. Chem. Soc. Rev., 2010, 39, 3351-3357. 